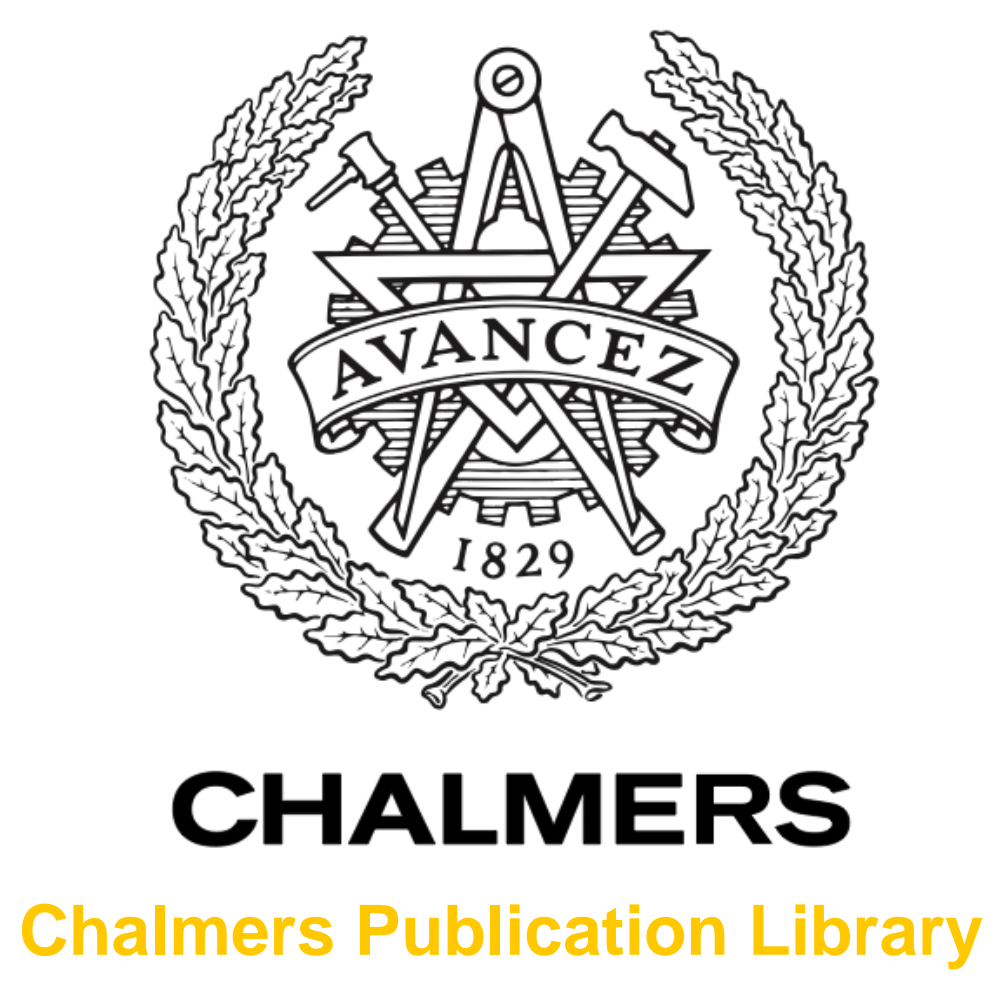

Implications of cost overruns and time delays on major public construction projects

This document has been downloaded from Chalmers Publication Library (CPL). It is the author's version of a work that was accepted for publication in:

Proceedings of the 19th International Symposium on the Advancement of Construction Management and Real Estate, 7-9 Nov 2014, Chongqing

Citation for the published paper:

Adam, A. ; Josephson, P. ; Lindahl, G. (2014) "Implications of cost overruns and time delays on major public construction projects". Proceedings of the 19th International Symposium on the Advancement of Construction Management and Real Estate, 7-9 Nov 2014, Chongqing

Downloaded from: http://publications.lib.chalmers.se/publication/206068

Notice: Changes introduced as a result of publishing processes such as copy-editing and formatting may not be reflected in this document. For a definitive version of this work, please refer to the published source. Please note that access to the published version might require a subscription. 


\title{
Implications of Cost Overruns and Time Delays on Major Public Construction Projects
}

\author{
Abderisak Adam, Per-Erik Josephson and Göran Lindahl
}

\begin{abstract}
For decades, the construction industry has been characterized by costs exceeding budgetary limits and completion times reaching further than what was set out initially. This has been particularly noticeable for large public construction projects where cost overruns and time delays have long been regarded a common occurrence. Due to the magnitude and frequency of these overruns, they have come to pose a significant financial risk to both clients and contractors, in addition to the impact exerted on the sustainability of the project.

In dealing with this, researchers, auditors and practitioners have suggested a broad range of solutions, ranging from technical and economical to psychological and political approaches. In doing so, the contractor's role has been emphasized whereas the role of the client organization has often been overlooked. This paper which is based on a literature review investigates the occurrence of and the explanations for cost overruns and time delays in major construction projects from the public client's perspective. It also explores the implications of cost overruns and time delays; the purpose of which is to offer an extended understanding of the relationship between the client's actions and effects on cost, time and sustainability parameters.
\end{abstract}

Keywords Cost overruns • Time delays • Infrastructure • Sustainability

\author{
A. Adam ( $\triangle)$ \\ Department of Civil and Environmental Engineering. Chalmers University of \\ Technology, Gothenburg, Sweden. \\ e-mail: abderisak.adam@chalmers.se \\ P-E. Josephson \\ Department of Civil and Environmental Engineering. Chalmers University of \\ Technology, Gothenburg, Sweden. \\ e-mail: per-erik.josephson@chalmers.se \\ G. Lindahl \\ Department of Civil and Environmental Engineering. Chalmers University of \\ Technology, Gothenburg, Sweden. \\ e-mail: goran.lindahl@chalmers.se
}




\section{Introduction}

For decades, the construction industry has been plagued by cost overruns (Akinci \& Fischer, 1998). Unrelenting in its severity, the mere mention of a construction project by media outlets, especially infrastructure projects of considerable size, has become more or less tantamount to costs exceeding budget and completion times reaching further than what was set out initially (Morris, 1990;Raftery, 2003; Siemiatycki, 2009;). The public's perception can hardly be deemed unwarranted as made evident by the staggering number of projects that go beyond budgetary limits. According to a study by Moms and Hough, a sizable majority (63\%) of 1778 construction projects funded by the World Bank exceeded their budgets (as cited in Baloi \& Price, 2003).

The case is further aggravated when it comes to large infrastructure projects such as rail and road construction in which Flyvbjerg et al. (2013) reports that a large share of such projects exceed their initial budgets with cost increases of 50$100 \%$ being commonplace and increases beyond $100 \%$ not unheard of. In stating these figures, Flyvbjerg et al. not only shed light on the severity of the problem, but also its global implications. The data upon which the study is based has been gathered from a range of different geographical locations, spanning five continents, 20 countries, both developed and developing nations, from late 20's to the late 90's. This shows that the challenge of cost overruns is clearly a global phenomenon and although there are minor differences depending on the geographical location, the problems persist in every continent. The situation is even more dire in the developing world where corruption carries a significant impact on actual costs and accounts for $10-30 \%$ of the value of a single construction contract (World Bank, 2012).

More significantly, while there has been strong interest in sustainability as it relates to urban development, there's been a lack of clarification as to what constitutes as sustainable in the public construction context, most notably in relation to infrastructure projects. Questions regarding how sustainability can be quantified and the key contributors of sustainability in the urban context have all, to a large degree, been left undealt with (KPMG, 2012).

\section{Research Methodology}

This paper explores the impact that cost overruns and time delays exert on the sustainability of large public construction projects. In particular, the study focuses on uncovering the causes underlying cost overruns and time delays in large public construction projects; these causes are subsequently examined in relation to their impact on the projects' sustainability.

Though the study encompasses large public construction projects in general, the lion's share of projects covered in this study relate primarily to infrastructure 
projects as these are the most prevalent type of large scale public projects discussed in the research literature.

In order to investigate the aforementioned research objectives, a literature study was carried out. The literature covered consisted predominately of empirical studies discussing cost overruns, time delays and sustainability in public construction projects.

\section{Literature Review}

This section describes the challenges that cost overruns and time delays pose on large scale public construction projects and how these challenges impact the sustainability of the projects.

\section{Reining in Expenses - Cost Overruns and Public Construction Pro- curement}

Jahren and Ashe (1990) demonstrated the existence of a correlation between project size and cost overruns showing that the larger the construction project is, the greater the percentage cost overrun will be. Similar results were obtained by Shrestha et al. (2013) who in a study of 363 public construction projects found that a greater project size resulted in more substantial cost overruns. These projects, often referred to as mega projects, are defined in terms of their expensiveness, physical nature and their impact on society leading to increased public attention (Altshuler \& Luberoff, 2003). Various estimates are used as a criterion for what constitutes a mega project, The U.S Federal Highway Administration (FHWA, 2004) state that projects in in excess of $\$ 1$ billion can be considered mega projects, other common estimates include half a billion U.S dollars (Flyvbjerg, 2004) and 250 million U.S dollars (Altshuler \& Luberoff, 2003).

Flyvbjerg makes the case that the definition of a mega project differs depending on the geographical setting, thus what might constitute a mega project in a more rural area might not be considered as such in a metropolis (Flyvbjerg, 2004). Though there appears to be a strong indication that a large project size will yield higher cost overruns, conflicting views have also been reported. Odeck (2004) investigated cost overruns in exclusively road projects showing that smaller project sizes contributed to lower cost overruns than larger ones, an observation that Odeck attributed to larger road projects having been under better management than their smaller counterparts. Although Odeck does not offer an explanation for the contrary results, Cantarelli et al. (2010) proposes that the conflicting results may be due to the small sample size of large projects listed in that study.

The passing of time seem to have had little effect on curbing cost overruns. Instead, the trend has marched towards the undertaking of larger and more costly projects; "never" remarks Flyvbjerg (2007, p. 3) "have so many expensive, largescale projects been built over so short a historical period which consequently entails significantly higher economic risks.” On a similar note, Shrestha et al. (2013) 
could not find any correlation between project completion year and cost overruns, suggesting that the situation was not improving over time. These findings run contrary to those by Randolph et al. (1987) who indeed did establish a correlation between project completion year and cost overruns. The differing results were attributed to whether or not the construction planning systems had been significantly altered during the time period in question. In the study by Shrestha et al. (2013), the construction practices in the studied region had not been changed significantly over the time interval studied and for that reason; the cost overrun figures saw no drastic variation. It may also suggest something entirely different. Granted that both the construction technology and the techniques for estimating costs have improved with time, the observation that level of cost increases still persist may instead suggest that the root of the problem is not engineering nor accounting but rather in the realm of politics (Altshuler \& Luberoff, 2003).

Furthermore, price increases have been identified by both governmental agencies (The Swedish National Audit Office, 2010) as well as by researchers (Morris, 1990; Mosey, 2009) as one of the chief causes for cost overruns. Morris (1990) argues that approximately $20-25 \%$ of all cost overruns can be attributed to price increases. The remainder can be traced to different factors of which the most important are: poor design and implementation, inadequate project funding, bureaucratic indecisiveness and the lack of coordination between enterprises. This view is not necessarily shared by project managers as shown in a study by Brunes and Lind (2014) in which it was found that the majority of the respondents in the observed sample size of 101 project managers were either unsure (32\%) or opposed (48\%) to the idea that price increases was a [common] cause of cost overruns. In addition to the factors mentioned above, the time to deliver the project will also affect whether or not cost overruns will occur (Morris, 1990).

The many intricacies of construction projects allow for a large number of cost increasing causes to emerge, thereby elevating the risks and uncertainties involved. The trend toward larger projects with increased complexity results in greater cost and schedule variations which in turn produces unsuccessful ventures (Abdelgawad \& Fayek, 2010).

In order to appropriately discuss the large plethora of causes, it becomes necessary to categorize each cost with respect to a specific domain. This is what Cantarelli et al. (2010) set out to do in a review of some of the most prolific reports and papers that deal with explanations for cost overruns. The authors conclude that the general consensus of researchers showed that political explanations constituted the primary source for cost overruns in large infrastructure projects. Included in this category were cost underestimation and forecast manipulation that were also identified as primary causes (Cantarelli, et al., 2010). This forecast manipulation occurs as a byproduct of incorrect assumptions about traffic flows.

Having established the occurrence of incorrect forecasts, Wachs' (1989) proposes a number of explanations to account for the phenomenon, most notably; that planners are either intentionally producing inaccurate forecasts or the tools to produce these forecasts are inadequate insofar as their utility to produce accurate es- 
timations. In regards to the first point, Wachs' asserts that data is fudged in order to support a more politically sound narrative by using traffic flows that are not representative of the proposed area and in some cases, the figures are downright fabrications. The lack of ethics can in certain cases cause planners to produce estimates that support a predetermined goal, disregard weaknesses in estimations and find consultants who are willing to produce such numbers, disavowing those who refuse.

In general, causes for cost overruns can be attributed to political, economic, technical or psychological causes. Moreover, each category involves a different explanatory narrative and should therefore be dealt with a different and suitable theoretical model. Whereas political explanations can be explained by Machiavellian theory (focuses on power and influence) or agency theory (focuses on motives based on self-interest), technical explanations may be explained through planning and forecasting theory. Likewise, economical explanations necessitate economic theories such as neoclassical economics or rational theory whereas psychological explanations fall under prospect theory (Cantarelli, et al., 2010).

In a Norwegian study of road constructions, it was shown that cost overruns tended to rise when the planned completion time was shorter. A number of explanations to this were considered; it may be that uncertainties decrease when project time increases as cost predictions become easier to formulate. It may also be due to the project management team improving their ability to oversee the chief causes of cost overruns which in turn is facilitated by the lengthier project time (Odeck, 2004). Though a planned completion time that is short in duration is advantageous in terms of cost overruns, a lengthy planning process is not. Overly complicated and lengthy planning initiatives have become standard in both OECD countries as well as non-members nations (OECD, 2007). This is certainly the case in the Swedish transportation sector where overly complex planning processes has been identified as a central problem in domestic infrastructure projects (The Swedish National Audit Office, 2010). A common response to this is to emphasize initiatives that serve to increase the capabilities of the client organization in handling projects of such complexity.

This line of thought is most vividly expressed by auditors who have been assigned to investigate the causes and remedies of cost overruns (Siemiatycki, 2009). Unlike researchers who have studied the phenomenon of cost increases in construction and transportation, auditors have had the benefit of an inside view from inside the governmental client organization lending them greater access to internal data. Consequently, this inside view has shaped their understanding of both the causes for cost overruns as well as possible remedies to alleviate the situation. Researchers, on the other hand, have largely been outside observers and thereby been able to broadly define the mandate of their studies and to take on an interdisciplinary approach. This approach has emanated in researchers focusing on the need for developing technological processes, uphold incentive structures that rewards accurate cost estimations and that discourages optimism bias (Siemiatycki, 2009). 


\section{Curbing Time Delays in Public Construction Projects}

In similitude to cost overruns, scheduling delays for construction projects are a common occurrence (Anastasopoulos, et al., 2012). In order to mitigate the risk of time delays occurring, a number of contractual schemes can be put in place such as the use of liquidated damages. It is not uncommon for a provision to be included in the contract stating that punitive damages must be paid by the contractor to the client in the event of a time delay for which the contractor is responsible. In general, such delays do not necessarily result in liquidated damages (Bordat, et al., 2004). Likewise, not all delays can be attributed to the contractor. Scheduling delays are typically divided into: a) excusable delays; b) compensable delays; and c) nonexcusable delays. The first category refers to delays in which neither the client nor the contractor can be assigned blame, typically a force majeure clause is included in the contract to addresses this. Compensable delays are those where the contractor is owed a compensation for delays caused by an unwarranted course of action taken by the client. This might consist of changes in the scope of the project or change of site conditions that differ from what the client stated. Nonexusable delays refer to delays caused by the actions or lack of action by the contractor and where the client may be subject to compensation from the contractor (Kraiem \& Diekmann, 1987).

It may be of interest to note that a considerable amount of research has been conducted investigating the cause behind nonexusable delays, a focus on the contractor's role and not the client's (Majid \& McCaffer, 1998). The classification of delays into the aforementioned groups, though useful, does not necessarily offer a complete account of time related complications. Instead, as Arditi and Pattanakitchamroon (2006) points out, there are several different situations in which it becomes difficult to assign the cause of a delay to a specific party. This in turn renders it difficult to enforce legal ramifications in terms of which party should compensate the other. This is particularly palpable in the case of concurrent delays, a type of project delay whereby two or more delays occur simultaneously, either of which would have caused the entire project to exceed the time limit had it occurred by itself (Rubin, 1983). In order to mitigate the occurrence of time delays managers must first be able to identify the lead causes behind time delays as this constitutes an essential step in finding a suitable solution. To achieve this, Majid and McCaffer (1998) analyzed eight studies involving over 900 construction organizations in order to identify 21 factors that contributed to delays in completion times.

Following this, the authors ranked each factor in terms of the impact that it exuded on the project's duration. Most notably: late deliveries, damaged goods and poor planning were identified as the most influential factors in causing time delays (Majid \& McCaffer, 1998). A common manifestation of poor planning is the occurrence of change orders. It offers an indication that events did not pan out as originally intended and tends to lead to both longer completion times as well as increased cost due to the purchase of new materials. Similarly, Josephson et al. 
(2002) highlight how rework has become an endemic occurrence in the world of construction, causing both cost overruns and time delays.

Despite this being the case, it may not be entirely feasible to eliminate change orders and rework altogether for as Bordat and Sinha (2004) points out, few construction projects are exempt from the advent of unforeseen circumstances and projects are therefore rarely completed without changes from the owner. Instead, efforts should be taken to minimize the frequency by which they occur.

The high risk nature of the construction industry serves to obfuscate the driving forces behind cost increases (Akinci \& Fischer, 1998). Specifically, it becomes difficult to assign responsibility to the actor who primarily caused the surge in costs. It thereby becomes possible for different interpretations to emerge as different groups of stakeholders assign blame to divergent causes, an observation made palpable by Kumarasmawy and Chan's (1998) study documenting the different viewpoints of contractors, consultants and clients in regards to the source of cost overruns. The survey based study found wide disagreements among the 147 respondents in regards to the type of factors that causes time overruns in construction projects. According to the response by contractors, the chief causes for delays were due to postponements in design information, lengthy duration for approving drawings and inadequate site management. Conversely, consultants attributed delays to primarily unforeseen ground conditions, inadequate contractor experience and poor site management and supervision.

Furthermore, the length of the delay is also dependent on the type of project undertaken. Maintenance projects generally experience the most severe time delays (Bordat, et al., 2004). This may seem counterintuitive as pointed out by Bhargava et al. (2010), maintenance projects are after all fairly standardized and one might then expect them to be less prone to cost overruns and time delays. On the contrary, road maintenance projects are frequently associated with unpredictable and unforeseen site conditions that often require the relocation of utilities and redirection of traffic flow which in turn tends to result in significant time delays.

Whereas maintenance projects were most problematic in terms of time delays, Bordat et al (2004) found that bridge and resurfacing projects were consistently better with respect time delays (one average 94 and 101 day respectively, compared to 153 days for maintenance projects). In similitude to cost overruns, the more expensive projects tended to result in more significant time delays.

\section{Relationship between time delays and sustainability}

Sustainability in construction is a comprehensive topic with many different facets; it includes a range of topics from air, water and noise pollution to ecological impacts (Shen, et al., 2007). Time delays have a direct impact on sustainability since an increase in project delivery time is associated with traffic congestion, delays, economic activities being disrupted, increased pollution, damage to ecosystems, and an impact on existing infrastructure systems (Gilchrist \& Allouche, 2005). 


\section{Discussion and Conclusion}

This section contains an abridged list of the most common causes behind cost overruns and time delays in public construction projects, based on prevalent research literature on the topic. Though some factors are more frequently mentioned than others, this does not necessarily imply that they are more influential in determining the scale of the cost overruns and/or delay. Indeed, the frequency by which a particular cause is mentioned may instead offer an indication of it being easily observable as opposed to having a greater impact.

Table 1: Causes of client related cost overruns and time delays in construction projects.

\begin{tabular}{|c|c|c|c|}
\hline Root cause & Study type & Cost overruns & Delays \\
\hline $\begin{array}{l}\text { Communication } \\
\text { - Lack of communication } \\
\text { between contractors and } \\
\text { clients } \\
\text { - Inefficient communica- } \\
\text { tion }\end{array}$ & Qualitative & & $\begin{array}{l}\text { (Majid \& McCaffer, } \\
\text { 1998) } \\
\text { (Chan \& } \\
\text { Kumaraswamy, 1997) }\end{array}$ \\
\hline $\begin{array}{l}\text { Management } \\
\text { - Poor site management } \\
\text { - Inadequate managerial } \\
\text { skills } \\
\text { - Poor monitoring } \\
\text { and control } \\
\text { - Slow decision making }\end{array}$ & $\begin{array}{l}\text { Qualitative } \\
\text { Quantitative }\end{array}$ & $\begin{array}{l}\text { (Cantarelli, et al., } \\
\text { 2010; Morris, } \\
\text { 1990) }\end{array}$ & $\begin{array}{l}\text { (Majid \& McCaffer, } \\
\text { 1998; Morris, 1990) } \\
\text { (Chan \& } \\
\text { Kumaraswamy, 1997; } \\
\text { Anastasopoulos, et al., } \\
\text { 2012) }\end{array}$ \\
\hline $\begin{array}{l}\text { Personnel } \\
\text { - Shortage of managerial } \\
\text { and supervisory staff } \\
\text { - Shortage of skilled labor } \\
\text { - Lack of experience } \\
\text { - Low motivation } \\
\text { - Too many responsibili- } \\
\text { ties }\end{array}$ & Qualitative & & $\begin{array}{l}\text { (Majid \& McCaffer, } \\
\text { 1998) } \\
\text { (Chan \& } \\
\text { Kumaraswamy, 1997) }\end{array}$ \\
\hline $\begin{array}{l}\text { Organizational } \\
\text { - Unsuitable management } \\
\text { structure } \\
\text { - Poor organization struc- } \\
\text { ture }\end{array}$ & $\begin{array}{l}\text { Qualitative } \\
\text { Quantitative }\end{array}$ & $\begin{array}{l}\text { (Cantarelli, et al., } \\
\text { 2010) }\end{array}$ & $\begin{array}{l}\text { (Chan \& } \\
\text { Kumaraswamy, 1997) }\end{array}$ \\
\hline Planning & Qualitative & (Cantarelli, et al., & (Majid \& McCaffer, \\
\hline
\end{tabular}


- Client initiated change orders

- Inadequate design specs

- Rework

- Poor labor planning

\section{Site conditions \\ - Unforeseen ground con- ditions}

\section{Weather}

- Harsh weather conditions

\section{Project related}

- Project complexity

- Project duration

(1)

Quantitative

Qualitative

Quantitative

Qualitative

Quantitative

(Bhargava, et al., 2010)

1990)

(Jahren \& Ashe, 1990)

998; Han, et al., 2009; Morris, 1990)

(Chan \&

Kumaraswamy, 1997)

(Han, et al., 2009)

(Chan \&

Kumaraswamy, 1997)

\section{(Chan \&}

Kumaraswamy, 1997; Bhargava, et al., 2010; Anastasopoulos, et al. 2012)

Qualitative

Quantitative

(Bhargava, et al., 2010; Bordat, et al., $\quad$ Kumaraswamy, 1997; 2004; Odeck, 2004; $\quad$ Bhargava, et al., 2010; Jahren \& Ashe, $\quad$ Bordat, et al., 2004; 1990) Anastasopoulos, et al., 2012)

\section{Material related \\ - Shortage of equipment \\ - Poor material planning}

\section{Process related}

- Poor procedures

\section{Psychological}

- Optimism bias

- Deception

\section{Financial}

- Delayed payment to
Qualitative

Quantitative

(Majid \& McCaffer, 1998)

(Chan \&

Kumaraswamy, 1997)

Qualitative

Quantitative

(Siemiatycki, 2009) (Majid \& McCaffer, 1998)

Qualitative (Flyvbjerg, et al., 2009; Flyvbjerg, et al., 2003;

Cantarelli, et al., 2010; Siemiatycki, 2009)

Quantitative

Qualitative

(Majid \& McCaffer, 1998) 
contractors/consultants

- Poor financial planning

Price related

- Price increases
Quantitative

Qualitative

Quantitative
(Mosey, 2009;

Morris, 1990)

(The Swedish

National Audit

Office, 2010)

The results in the table do not take into account factors that are outside of the control of the client, for instance the lack of communication between contractors and consultants which does have an impact on cost overruns and time delays (Chan \& Kumaraswamy, 1997). However causes such as this does not relate directly to the client organization and are therefore omitted.

It ought to be mentioned that the above categorization is merely a simplification and that the causes determining cost overruns and time delays often intersect (Bhargava, et al., 2010). For instance, it may be argued that rework is a subset of improper planning and that deception is an indication of bad hiring policies. In understanding the underlying causes, it may therefore be prudent, like Cantarelli et al (2010), to distinguish between causes and explanations. The former consist of the singular factors resulting in an effect (i.e. cost overruns and/or time delay) whereas the latter attempt to offer a broader and more general description of what may have transpired that led to the subsequent effect. An explanation could therefore consist of several causes. This is illustrated well in the case of sustainability; take the case of a construction project that causes severe disturbances to the local milieu through excessive amounts of noise and congestion. It may be as Majid and McCaffer (1998) suggest that the cause can consist of improper planning which in turn is an indication of either inadequacies in the organizational structure that allows for such decisions to be made and/or the shortcomings of individual personnel assigned to the project. Irrespective of the first cause identified, other causes can be introduced to form a descriptive narrative. Thus, two projects may have the same primary cause determining a cost overrun or time delay but still have differing explanations. Each explanation is unique and path dependent to the project being studied and can therefore not be directly transferable to a different project. 


\section{References}

Abdelgawad, M. \& Fayek, A., 2010. Risk Management in the Construction Industry Using Combined Fuzzy FMEA and Fuzzy AHP. Journal of Construction Engineering Management, 136(9), pp. 1028-1036.

Akinci, B. \& Fischer, M., 1998. Factors affecting contractors' risk of cost overburden. Journal of Management in Engineering, 14(1), pp. 67-76.

Altshuler, A. A. \& Luberoff, D., 2003. Mega-projects: The changing politics of urban public investment. Washington, United States: Brookings Institution Press.

Anastasopoulos, P., Labi, S., Bhargava, A. \& Mannering, F., 2012. Empirical Assessment of the Likelihood and Duration of Highway Project Time Delays. Journal of Construction Engineering Management., 138(3), pp. 390-398.

Arditi, D. \& Pattanakitchamroon, T., 2006. Selecting a delay analysis method in resolving construction claims. International Journal of project management, 24(2), pp. 145-155.

Bhargava, A. et al., 2010. Three-stage least-squares analysis of time and cost overruns in construction contracts. Journal of construction engineering and management, 136(11), pp. 1207-1218.

Bordat, C., McCullouch, B. \& Sinha, K., 2004. An analysis of cost overruns and time delays of INDOT projects, Indiana, USA: Joint Transportation Research Program.

Brunes, F. \& Lind, H., 2014. Explaining cost overruns in infrastructural projects: A new framework with applications to Sweden. S-WoPEc, 14(1), pp. 140.

Cantarelli, C. C., Flyvbjerg, B., Molin, E. J. \& van Wee, B., 2010. Cost overruns in large-scale transportation infrastructure projects: Explanations and their theoretical embeddedness. EJTIR, 10(1), pp. 5-18.

Chan, D. W. \& Kumaraswamy, M. M., 1997. A comparative study of causes of time overruns in Hong Kong construction projects. International Journal of Project Management, 15(1), pp. 55-63.

Federal Highway Administration, 2004. Megaprojects - They are a Different Breed. Public roads, 68(1), pp. 2-9.

Flyvbjerg, B., 2004. Megaprojects and risk: a conversation with Bent Flyvbjerg. Critical Planning, Volume 11, pp. 51-63.

Flyvbjerg, B., Garbuio, M. \& Lovallo, D., 2009. Delusion and Deception in Large Infrastructure Projects: Two Models for Explaining and Preventing Executive Disaster. California Management Review, 51(2), pp. 170-193.

Flyvbjerg, B., Skamris Holm, M. K. \& Buhl, S. L., 2003. How common and how large are cost overruns in transport infrastructure projects?. Transport Reviews, 23(1), pp. 71-88.

Gilchrist, A. \& Allouche, E. N., 2005. Quantification of social costs associated with construction projects: state-of-the-art review. Tunnelling and underground space technology, 20(1), pp. 89-104. 
Han, S. H. et al., 2009. Analyzing schedule delay of mega project: Lessons learned from Korea train express. Engineering Management, IEEE Transactions on, 56(2), 243-256.. IEEE Transactions on Engineering Management, 56(2), pp. 243-256.

Jahren, C. T. \& Ashe, A. M., 1990. Predictors of cost-overrun rates. Journal of Construction Engineering and Management, 116(3), pp. 548-552.

Josephson, P. E., Larsson, B. \& Li, H., 2002. Illustrative benchmarking rework and rework costs in Swedish construction industry. Journal of Management in Engineering, 18(2), pp. 76-83.

KPMG, 2012. Cities Infrastructure: A Report On Sustainability, s.l.: KPMG International Cooperative.

Kraiem, Z. M. \& Diekmann, J. E., 1987. Concurrent delays in construction projects. Journal of Construction Engineering and Management, 113(4), pp. 591602.

Kumaraswamy, M. M. \& Chan, D. W., 1998. Contributors to construction delays. Construction Management \& Economics, 16(1), pp. 17-29.

Majid, M. A. \& McCaffer, R., 1998. Factors of non-excusable delays that influence contractors' performance. Journal of Management in Engineering, 14(3), pp. 42-49.

Morris, S., 1990. Cost and time overruns in public sector projects. Economic and Political weekly, 25(47), pp. 154-168.

Mosey, D., 2009. Early Contractor Involvement in Building Procurement: Contracts, Partnering and Project Management. UK: Wiley-Blackwell .

Odeck, J., 2004. Cost overruns in road construction - what are their sizes and determinants?. Transport Policy, 11(1), pp. 43-53.

OECD, 2007. Infrastructure to 2030 (Vol. 2): Mapping Policy for Electricity, Water and Transport, Paris, France: OECD Publishing.

Raftery, J., 2003. Risk analysis in project management. s.l.:Routledge.

Randolph, D. A., Rajendra, K. \& Campfield, J. J., 1987. Using risk management techniques to control contract costs. Journal of Management in Engineering, 3(4), pp. 314-324.

Rubin, A. R., 1983. Construction claims: analysis, presentation, defense. New York, USA: Van Nostrand Reinhold.

Shen, L. Y., Li Hao, J., Tam, V. W. Y. \& Yao, H., 2007. A checklist for assessing sustainability performance of construction projects. Journal of Civil Engineering and Management, 13(4), pp. 273-281.

Shrestha, P., Burns, L. A. \& Shields, D. R., 2013. Magnitude of Construction Cost and Schedule Overruns in Public Work Projects. Journal of Construction Engineering, 2013(Article ID 935978).

Siemiatycki, M., 2009. Academics and Auditors Comparing Perspectives on Transportation Project Cost Overruns. Journal of Planning Education and Research, 29(2), pp. 142-156.

The Swedish National Audit Office, 2010. Cost control of large road investments? , Stockholm, Sweden: RiR 2010:25. 
Wachs, M., 1989. When planners lie with numbers. Journal of the American Planning Association, 55(4), pp. 476-479.

World Bank, 2012. Construction Sector Transparency Program Goes Global. [Online]

Available at: http://www.worldbank.org/en/news/feature/2012/11/08/constructionsector-transparency-program-goes-global

[Accessed 1408 2014].

WSP, 2011. Hantering av kostnadsfördyringar - Ett stöd till projektledaren (Managing Cost Overruns - an Aid for the Project Manager), Stockholm, Sweden: WSP Sverige AB. 